\title{
Prelazak astrologije iz sfere znanosti u domenu pučke literature u tekstovima hrvatskih autora 18. i 19. stoljeća
}

Marijana Borić*

\begin{abstract}
Sažetak
Astrologija kao tema prisutna je u radovima niza istaknutih hrvatskih autora $u$ razdoblju od srednjovjekovlja pa sve do 19. stoljeća. Javlja se u različitim oblicima, sadržajima i formi, od zapaženih djela prožetih egzaktnim znanostima $i$ filozofijom do zabavnih tekstova u literaturi pisanoj za puk. Rad govori o novovjekovnim transformacijama i pristupu astrologiji, nakon njezina isključivanja iz sfere znanstvenih i filozofskih koncepcija, što se odražava i u djelima hrvatskih autora 18. i 19. stoljeća.

Ključne riječi: astrologija; astronomija; filozofija; Pavao Ritter Vitezović; Josip Franjo Kosednar; Ivan Maurović; astrološki rukopisi; pučka literatura
\end{abstract}

\section{Uvod}

Astrologija je disciplina čiji korijeni sežu još u bakreno doba i kontinuirano je prisutna sve do današnjih dana. Drevna se astrologija može smatrati jednim od ranih pokušaja razumijevanja svijeta i tumačenja povezanosti sublunarnoga i supralunarnoga područja kroz uporabu simboličkih slika. Prilagođavajući se različitim religijskim, kulturološkim, znanstvenim i filozofskim konceptima, astrologija se tijekom stoljeća pojavljivala u vrlo različitim formama i sadržaju. Jedan je od oblika divinacije, ${ }^{1}$ čija tehnika predviđanja ne ovisi o nadahnuću, nego se

* Dr. sc. Marijana Borić, Hrvatska akademija znanosti i umjetnosti. Zavod za povijest i filozofiju znanosti. Adresa: Ante Kovačića 5, 10000 Zagreb, Hrvatska. ORCID iD: https://orcid.org/00000002-0044-0888. E-adresa: mbuljan@hazu.hr. Ovaj rad financirala je Hrvatska zaklada za znanost projektom Hrvatska znanstvena i filozofska baština: transferi i aproprijacije znanja od srednjega vijeka do dvadesetoga stoljeća u europskome kontekstu (IP-2016-06-6762).

1 Divinacija je jedan od oblika predviđanja. Temelji se na mitsko-religioznim pretpostavkama koje služe u oblikovanju tumačenja. Pojavljuje se u različitim oblicima, među kojim se ističu predviđanje na temelju tumačenja sna. Astrologija je najčešći oblik divinacije, te se često kroz povijest izjednačavala s divinacijom (Skuhala Karasman, 2013, 28). 
njezina tumačenja oslanjaju na poznavanje konstelacija i gibanja pojedinih planeta. Astrološko predviđanje temelji se isključivo na astrološkim metodama i tehnici izrade proračuna te na interpretaciji dobivenih rezultata. Kroz povijest odražavala je misao o prožimanju čovjeka i kozmosa te se smatrala korisnom znanstvenom i praktičnom disciplinom. ${ }^{2}$ Akumulacija znanja tijekom renesanse te pojava novih ideja (heliocentrični sustav, beskonačnost svemira te novi filozofski i znanstveni koncepti) uz uvođenje novoga metodološkoga pristupa istraživanjima, u kojem empirija konvergira s primjenom matematičkih metoda, postupno je dovelo do novovjekovnoga obrata i nastanka novoga svjetonazora, koji pred astrologiju postavlja zadatak reforme (Skuhala Karasman, 2013, 82 i 121). U pokušaju novoga utemeljenja astrologije sudjelovali su glasoviti učenjaci toga doba (Galileo Galilei, Tycho Brahe, Johannes Kepler i dr.). Usprkos njihovim nastojanjima, astrologija nakon toga perioda više nije mogla ispuniti zahtjeve koji se postavljaju pred znanost u metodološkom smislu, te je nestala iz korpusa znanosti, ali i nakon toga vremena interes za nju nije jenjavao.

\section{Astrološki tekstovi u hrvatskim kalendarima 18. i 19. stoljeća}

Prvi niz pučkih kalendara na hrvatskom jeziku objavljivao je Pavao Ritter Vitezović od 1691. do 1705. godine. Bili su namijenjeni gradskomu puku i odražavali senzibilitet svojega vremena, te su uz uobičajene kalendarske podatke i rubrike donosili bogate astrološke priloge, slične strukture i sadržaja koje su u to vrijeme sadržavali i kalendari tiskani u zapadnoeuropskim zemljama.

Analiza Vitezovićevih kalendara pokazuje da je među raznolikim sadržajem koji donose astrologija najopširnije zastupljena tema. Obrađuje se u nekoliko različitih poglavlja i rubrika. Ti tekstovi ne sadrže astrološku teoriju kao ni tumačenja astroloških postupaka i računa koji se koriste u astrološkoj praksi. Također nisu iznesena ni gledišta u svezi s astrologijom, nego su dani osnovni podatci u vezi s godišnjim gibanjima planeta, potrebni za astrološke prognoze, i raznovrsni astrološki prilozi. Vitezović razmatra prolazak Sunca kroz Zodijak i u skladu s gibanjima planeta prema zviježđu životinjskoga pojasa izlaže karakteristike zodijačkih znakova te donosi tabele s razdobljima vladavina pojedinih planeta. Za sve planete daje opsežne podatke o njihovim gibanjima, također donosi i međusobne položaje planeta potrebne za izradu astroloških tumačenja i prognoza kroz godi-

2 Astrologija razmatra široki spektar područja, od života pojedinca i cijelih naroda do meteoroloških pojava te različitih promjene na Zemlji, kao i primjenu astroloških utjecaja u zemljoradnji, politici i ekonomiji. Stoga se s obzirom na područja koja obuhvaća dijeli na nekoliko oblika. Najstariji oblik astrologije je omen-astrologija. Koristila se za predviđanje i tumačenje nebeskih i meteoroloških pojava te njihovu primjenu u gospodarstvu (Skuhala Karasman, 2013, 83-84). Genetlialogija je područje astrologije koje se bavi izradom osobnih horoskopa, određivanjem sudbina, karaktera i osobina pojedinca na temelju astralne konstelacije u trenutku rođenja ili začeća. Opća astrologija razmatra prognoze većih skupina, poput gradova ili cijelih naroda, a područje astrologije koje se bavi određivanjem najpovoljnijega trenutka za postizanje određenoga ishoda naziva katarkična astrologija. Danas je u medijima vrlo često prisutna astrologija trenutačnih pitanja, područje koje se bavi prognozama načinjenim na temelju trenutačne konstelacije. 
nu. S obzirom na količinu izloženih podataka, može se zaključiti da su Vitezovićevi kalendari vjerojatno bili namijenjeni gradskomu puku, odnosno čitateljima koji su već imali određena predznanja i bili upućeni u astrologiju. Činjenica da ih je tiskao kontinuirano punih petnaest godina potvrđuje pretpostavku da se u Hrvatskoj u to vrijeme još uvijek podržavala astrologija te da je postojalo živo zanimanje za nju.

Slijedeći niz astroloških kalendara Pavla Rittera-Vitezovića ${ }^{3}$, tragove sličnih astroloških priloga možemo pratiti u čitavom slijedu mlađih hrvatskih kalendara koji su od druge polovice 18. stoljeća postajali sve brojniji. ${ }^{4}$ Vitezovićevi kalendari ${ }^{5}$ bili su uzor i priređivačima u 19. stoljeću, kada su pučki kalendari prolazili kroz bitne transformacije te se je novo doba odražavalo i u njihovim sadržajima. Mlađi su priređivači kalendara koncepcijom često slijedili Vitezovićeve kalendare te se ponekada ponavljaju iste rubrike i slični tekstovi. ${ }^{6}$ Međutim, unosili su i druge teme pa su, pored zadržane forme ustaljenih rubrika, kalendari bili obogaćeni novim tekstovima, te su astrološki prilozi u odnosu na ostali sadržaj postali sve malobrojniji i manjega opsega. Promjene sadržaja posebno su prisutne kod bogatih prosvjetiteljskih kalendara tiskanih u 19. stoljeću. Ipak, budući da su razvoj i transformacije hrvatskih pučkih kalendara tekli postupno od njihovih početaka na prijelazu iz 17. u 18. stoljeće, još su dugo zadržavali sličnosti s Vitezovićevom koncepcijom. ${ }^{7}$ Vidljive su kod velikoga broja različitih djela iz bogate hrvatske kalendarske tradiciji: u Novom kalendaru (Zagreb, 1769.-1812.) Gregura Kapucina, zatim Horvatskom kalendaru (Zagreb, 1812.-1817.) Tomaša

3 Vitezović Ritter, Pavao. 1692., 1698., 1699, 1705, Meszecsnik hervatzki, Zagreb. Čuvaju se u Nacionalnoj i sveučilišnoj knjižnici u Zagrebu

4 O nastanku prvih pučkih kalendara vidi: Despot, Miroslava. 1972. "Kalendar, njegov postanak i razvoj", Kaj časopis za kulturu i prosvjetu V/12; 23-24

5 Od kalendara koje je kontinuirano petnaest godina priređivao i tiskao Vitezović danas su sačuvani samo poneki primjerci. Nacionalna i sveučilišna knjižnica u Zagrebu posjeduje kalendare za 1692., 1698., 1699. i 1705. godinu.

6 Uvodni dio kalendara donosi opće podatke i komputske podatake za tekuću godinu, a uz njih Vitezović u kalendarima tiska uvodni astrološki dio naslova Dvanaest znamenov nebeskih ztumacsenje, u kojem daje pregled astroloških naziva, njihovih znakova i simbola koje koristi u daljnjem tekstu. Tomu dodaje Ztumacsenje ostalih znamenki, kratki tabelarni prikaz svih simbola i kratica koje se pojavljuju u kalendaru načinjen u tri stupca. Daje simbole planeta i njihove nazive te navodi astrološke aspekte (konjunkcija, opozicija, trigon, kvadrat i sekstil), koji se spominju još u antici. Opisao ih je u svojem djelu Tetrabiblos još u 2. st. pr. Kr. Klaudije Ptolemej Aleksandrijski, po kojem se nazivaju ptolomejskim aspektima. Zadržali su se u astrološkoj praksi sve do današnjih dana te čine glavnu sastavnicu svake astrološke analize. Vitezović donosi raznovrsne astrološke priloge i tumačenja. Premda njegovi kalendari sadržavaju dosta astronomskih podataka, ipak njihova intencija nije bila da poduči astronomskim sadržajima, nego su vjerojatno korišteni kao građa za izradu bogatih astroloških priloga, u to doba vrlo popularnih i prisutnih u svim zapadnoeuropskim kalendarima. Astrologija je do 17. stoljeća bila toliko cijenjena da su i mnogi ugledni astronomi kao Tycho Brahe i Johannes Kepler bili angažirani kao profesionalni astrolozi na dvorovima kraljeva i moćnika. Astrološkoj se literaturi u to vrijeme još uvijek poklanjao velik interes i važnost.

7 Opširnije vidi u radu: Borić, Marijana. 2016. Pavao RitterVitezović i njegov utjecaj na tradiciju hrvatskih kalendara. U: Zbornik radova sa znanstvenog skupa „Pavao RitterVitezović i njegovo doba (1652-1713) “, Zagreb, 26.-28. rujna 2013., Hrvatski studiji sveučilišta u Zagrebu,:279-299. 
Mikloušića, kao i u njegovu Stoljetnom kalendaru (Zagreb, 1819.), potom u Stoljetnom kalendaru (Zagreb, 1819.) Antuna Rožića, Horvatskom kalendaru (Varaždin, 1821.-1854.) Ivana Sangille i u bogatom almanahu Danica Zagrebečka (Zagreb, 1834.-1850.) Ignjata Kristijanovića, koji se smatra vrhuncem među prosvjetiteljskih kalendarima. Sličnost s Vitezovićevim kalendarima prisutna je i u djelima slavonskih priređivača kalendara: Kalendar ili uređeno prikazanje nedilja (Budim, 1746.-1780.) Emerika Pavića; Svetodanik illiti kalendar illyricski (Budim, 1778.-1786.) Marijana Lanosovića; Novi i stari svetodanik (Osijek, 1793.-1817.) Aleksandra Tomikovića; Novi i stari kalendar (Osijek, 1822.-1867.) Adama Filipovića Heldentalskoga; Novi i stari kalendar (Budim, 1836.-1855.) Ignjata Alojzija Brlića; Novi i stari kalendar (Budim, 1856.-1857.) Andrije Torkvata Brlića (Borić, 2014, str. 337-354).

Premda su mlađi kalendari uvodili nove rubrike, bili suvremeniji i obogaćeni širim opsegom tema, dijelom ipak zadržavaju staru koncepciju i pojedine rubrike, u što spadaju astrološki prilozi. Činjenica da su se kalendari mijenjali u skladu s novim vremenom, nije dovela do potpunoga odbacivanja astroloških priloga, te su se oni nastavili objavljivati u različitom opsegu, ovisno o afinitetima priređivača. Neki od navedenih kalendara izlazili su svega po koje godište, stoga su za usporedbu najzanimljiviji oni najutjecajniji i najduže upotrebljavani, koji su kontinuirano izlazili po dvadesetak ili tridesetak godina. Općenito gledajući, hrvatski se pučki kalendari nakon druge polovice 18. stoljeća transformiraju u poučna i praktična štiva, svakodnevne priručnike za najširi puk. Pisani su s ciljem prosvjećivanja i unaprjeđivanja života i gospodarstva i na tim je sadržajima naglasak, a astrologija je u drugom planu i vjerojatno joj je cilj bio zabaviti čitatelje. Kalendari iz toga perioda sadržavali su različite teme: prirodoznanstvene, astronomske, astrološke, kalendarske, meteorološke, gospodarske, farmakološke, veterinarske, poljodjelske i literarne, a u usporedbi s Vitezovićevim astrološkim kalendarima zamjetno je da je astrologija znatno manje zastupljena te da joj nije pridana ista važnost kao na prijelazu iz 17. u 18. stoljeće. U kalendarima od druge polovice 18. stoljeća prevladavaju gospodarski te prirodoznanstveni i astronomski tekstovi koji više nisu u službi astroloških rubrika i predviđanja kao kod Vitezovića, nego je njihov cilj pouka. Neki od tih kalendara bili su prave enciklopedije praktičnih znanja za unapređenje gospodarstva u najširem smislu riječi (Mikloušić, 1819). Pučki kalendari dragocjeni su materijal u kojem se reflektira duhovni i materijalni život vremena u kojem su nastali te odražavaju razinu kulturnoga i znanstvenoga konteksta pripadajuće sredine. Kao i sva potrošna roba, tako i kalendari s vremenom i nemarom postupno nestaju, stoga ih je potrebno čuvati, atribuirati i analizirati, jer upravo iz tih kalendara, kao skupova raznolikoga štiva koji zadiru u različite aspekte ljudskoga življenja, možemo iščitati i rekonstruirati različite segmente tadašnjega društva i njegova razvoja. ${ }^{8}$

8 Primjerice, tako je Emerik Pavić priređivao i objavljivao hrvatske kalendare u Budimu punih trideset i pet godina, od 1746. do 1780. godine, a danas je od svih izdanja sačuvan svega jedan primjerak otisnut za godinu 1766. naslova Kalendar ili uregjeno prikazanje nediljah $i$ svetkovinah (NSK u Zagrebu, sign. R II E 8-194). 


\section{Astrološko kolo Mate Zoričića}

Astrologija se u 18. stoljeću pored pučkih kalendara pojavljivala i u djelima drugih žanrova. Zanimljiv je astrološki prilog koji je priredio i u svoj matematički priručnik Aritmetika u slavni jezik illiricki dodao franjevac Mate Zoričić. Djelo je tiskao 1766. godine u Anconi i to je prva cjelovita knjiga s podukom iz matematike na hrvatskom jeziku koja se koristila u Dalmaciji. Dotada su u Hrvatskoj postojali samo priručnici i udžbenici iz matematike na stranim jezicima. U to vrijeme nastaje i prvi matematički udžbenik na hrvatskom jeziku Arithmetika horvatzka Mije Šiloboda Bolšića, koji se koristio na sjeveru Hrvatske. Zoričić je svoj matematički priručnik kao i Šilobod pisao prema nekoliko stranih predložaka, što i sam kaže u predgovoru knjige. Iako djelo nije izvorno, zbog duge i česte uporabe te značenja koje je imalo na razvoj matematičke terminologije i matematičkoga obrazovanja u Hrvatskoj, više je puta bilo detaljno analizirano i ocjenjivano u okvirima kulturne i znanstvene baštine. Zoričić je knjigu koristio u nastavi, ali ju je koncipirao tako da se može koristiti i šire, kao priručnik za nastavnike, trgovce, obrtnike, domaćine i najširi puk, jer je također htio svojom aritmetikom pomoći boljemu upravljanju životom i gospodarstvom, što u knjizi i navodi. Iz aspekta astrologije, posebno je zanimljivo posljednje poglavlje Zoričićeve aritmetike, u kojem donosi astrološko kolo. On ga naziva matematičko kolo, a sastoji se od vanjskoga kruga u koji su upisane uzastopne godine. Ispod njih, idući prema centru kruga, dane su pripadajuće astronomske oznake planeta koji vladaju u pojedinoj godini i prema sredini kruga ispod svake godine stoji naznačeno je li riječ o rodnoj ili nerodnoj godini. Prema izvornoj Ptolemejevoj koncepciji o sedam planeta na nebu, Zoričić kaže da godinom vlada sedam zvijezda: Sunce, Mjesec, Mars, Merkur, Jupiter, Venera i Saturn. Po njemu, godina će biti rodna kad njome vladaju Sunce, Mars i Jupiter, a nerodna kad vladaju Mjesec, Merkur, Venera i Saturn. Međutim, Zoričić broj sedam ne uzima za dužinu ukupnoga trajanja ciklusa jer se redoslijed planeta ne ponavlja nakon isteka sedam godina. On ciklus dominacije pojedinoga planeta temelji na broju dvadeset osam. Premda se to u knjizi nigdje ne spominje, riječ je o periodu iz komputskih računa, gdje se ciklus od dvadeset osam godina naziva Sunčev ili Zlatni krug. To je vremensko razdoblje nakon kojeg se svaki nadnevak poklapa s istim danom u tjednu. ${ }^{9}$ Zoričić to u knjizi nigdje ne tumači, nego u matematičkom kolu daje podatke za pojedine godine, počevši od 1763., kada je knjiga u rukopisu dovršena, pa redom dalje, zaključno s 1790., te kaže da se dalje tako započinje novi ciklus i slijedom nižu godine s jednakim rasporedom izmjena planeta koje vladaju pojedinom godinom. Važno je napomenuti da, premda je Zoričić u skladu s vjerovanjima i tendencijama 18. stoljeća, bio djelomično podložan astrološkim

9 Prema dogovoru, za početak prvoga perioda Sunčeva ili Zlatnoga kruga uzima se 9. godina pr. Kr. Prema tome se krug Sunca za promatranu godinu dobije ako se broju godina doda 9 i zbroj podijeli s 28. Ostatak je dijeljenja krug Sunca te godine. Primjer određivanja kruga Sunca za 2018. godinu: $2018+9=2027,2027: 28=72+$ ostatak 11. Dakle, godine 2018. krug Sunca je 11, a u tom vremenu protekla su 72 puna kruga Sunca. 
uvjerenjima svojega doba, u slučaju njegova matematičkoga kruga nipošto nije riječ o divinatornoj astrologiji. Naime, Zoričić nije sklon astrološkomu predviđanju vezanom uz ljudsku sudbinu i živote, što je njemu kao svećeniku u potpunosti neprihvatljivo. Njegovo zastupanje astroloških gledišta usmjereno je samo na urod u polju i u svojoj biti ograničeno je na korespondenciju vladajućih planeta s rodnošću ili nerodnošću zemlje. Njegovo je zastupanje astrologije bilo u skladu $\mathrm{s}$ Aristotelovom prirodnom filozofijom, koja je $\mathrm{u}$ to doba bila još potpuno zastupljena u filozofijama njegove franjevačke provincije. Ako se to uzme u obzir, shvatljivo je da je Zoričić mislio da i na taj način puku daje korisne upute (Dadić, 2004, 219). Takva vjerovanja bila su prisutna u raznim drugim oblicima pučke literature toga doba, ali i još dugo nakon njega.

\section{Astrološki rukopisi iz 18. stoljeća}

Pored opisanih astroloških tekstova i priloga na hrvatskom jeziku koji su tiskani u pučkoj literaturi tijekom 17., 18. i 19. stoljeća, od pisane astrološke baštine na hrvatskom jeziku iz toga perioda ostalo je svega nekoliko sačuvanih rukopisa. Do danas nisu detaljnije proučavani s astrološkoga ili astronomskoga gledišta ni s gledišta znanstvene terminologije. Sačuvana su ukupno četiri rukopisa nastala u 18. stoljeću. Dva su pisana u sjeverozapadnoj Hrvatskoj, a druga dva astrološka teksta sudeći po jeziku nastala su u Dalmaciji i Istri. Prva dva rukopisa dulja su i kraća verzija astrološko-astronomskog teksta Josipa Franje Kosednara. ${ }^{10}$ Opsežniji Kosednarov rukopis nastao je 1787. godine i na koricama nosi kratki naslov Cisio aliti Planetna Knjiga, a na unutrašnjoj naslovnici dugi je naslov, u kojem su sažeto zapisane u rukopisu zastupljene teme. ${ }^{11}$

\subsection{Cisio aliti Planetna Knjiga}

U 18. stoljeću kada je Kosednar pisao tekst Cisio aliti Planetna Knjiga u zapadnoeuropskim znanstvenim krugovima sve je više prevladavala Descartesova prirodna filozofija utemeljena na heliocentričnom sustavu te Newtonova, koja je, ujedinivši Galilejevu mehaniku i Keplerovu kozmološku sliku svijeta s općim zakonom gravitacije i temeljnim aksiomima gibanja, potisnula Aristotelovu peripatetičku filozofiju i geocentrizam, koji su se u to vrijeme zadržali još u školstvu. Godina 1757. označava prekretnicu kada Kongregacija kardinala briše iz Indeksa zabranjenih knjiga one koje naučavaju o gibanju Zemlje, a godine 1773. dokida

10 Podatci o životu i radu Kosednara vrlo su oskudni. Prema Rudolfu Strohalu, živio je u 18. stoljeću i bio dulje vrijeme altarist u Varaždinu, a osim dva već spomenuta rukopisa napisao je i Pitanje $k$ dragem domorocem slavneh orsagov dalmat. horvat. slavon: Magister, quid faci edo vitam aeternam possidebo i Mešter, kaj sem čineći, da žitek vekivečni zadobim?

11 Kosednarov rukopis Cisio aliti Planetna Knjiga čuva se u Nacionalnoj i sveučilišnoj knjižnici u Zagrebu pod signaturom R 3523, a preostala tri astrološka rukopisa na hrvatskom jeziku: kraći Kosednarov izvadak iz rukopisa Cisio aliti Planetna Knjiga te rukopisi Govoregnie od astrologie i od prilike naravne covika Ivana Antuna Remondinija i Knige mnogo lipe i korisne u kih se nahajaju planete Ivana Maurovića čuvaju se u Arhivu Hrvatske akademije znanosti i umjetnosti u Zagrebu. 
se i isusovački red. Te se promjene odražavaju i u našoj sredini, ali dosta polako. Općenito gledano, prirodne znanosti u Hrvatskoj bile su relativno slabo poznate $\mathrm{u}$ to vrijeme, uglavnom zbog humanističke orijentacije tadašnje nastave i rijetkih filozofskih tečajeva, na kojima je u većini slučajeva dominirala peripatetička prirodna filozofija. Tako su sačuvani rukopisi iz toga razdoblja gotovo uvijek još pisani u duhu peripatetičke filozofije, a tek se u manjem broju tekstova naslućuje odstupanje od Aristotelove filozofije u cjelini i transformacija prirodoznanstvenih pogleda u smislu prihvaćanja heliocentrizma, njutonizma i Boškovićeve teorije (Dadić, 1982, 36-37). U skladu s crkvenim učenjima, Kosednar se opredijelio za geocentrizam i peripatetičku prirodnu filozofiju. Takav odnos prema ustrojstvu svijeta mogao se očekivati, uzevši u obzir opću prirodoznanstvenu situaciju druge polovice 18. stoljeća u Hrvatskoj i činjenicu da je Kosednar pisao koristeći se dijelom mađarskim prijevodom jednoga od djela astronoma, astrologa i matematičara Johannesa Müllera Regiomontanusa iz 15. stoljeća, što u uvodnom poglavlju i sam naglašava. ${ }^{12}$ Budući da je astronomska teorija integralni dio astroloških tumačenja, uvodna poglavlja rukopisa donose osnovne astronomske podatke: o veličini Zemlje, o udaljenostima među planetima, međusobnom odnosu veličina Zemlje i ostalih planeta, vremenu ophodnje i drugo. Utjecaj aristotelizma prisutan je u astrološkim opisima planeta i zemaljskih objekata. Planetima su pridružena svojstva: toplo, hladno, suho ili mokro. Kosednar navodi kako je čovjek izgrađen od četiri elementa: vatre, zraka, vode i zemlje, koji svojim miješanjem transformiraju karakter. Onaj koji prevladava određuje čovjeku vanjski izgled, narav i sposobnosti. Među temama koje je Kosednar obradio dotiče se i područja astrometeorologije. Prognoze također tumači s pomoću četiri elementa i njihovih kvaliteta te uz utjecaj nebeskih tijela. Zastupa mišljenja da četiri elementa (vatra, zrak, voda i zemlja) imaju vrijeme u kojem vladaju te da je njihovim kvalitetama (toplo, hladno, suho, mokro) određeno buduće vrijeme, te na tom temelji prognoze. Kada govori o nebeskim tijelima, opisuje ih također $\mathrm{u}$ skladu s Aristotelovom prirodnom filozofijom. Komete pridružuje zemaljskomu, nesavršenomu i promjenjivomu području. Kosednar kao popratnu pojavu gromova opisuje pad meteorita. Vezu gromova i meteorita nalazimo i kod Lavoisiera, koji godine 1768. objašnjava pad meteorita kao kamen koji je udario grom, a ne kao kamen koji je pao s neba (Dadić, 1982, 282). Prema Kosednaru, meteoriti su također zemaljskoga podrijetla kao i kometi, čime u skladu s Aristotelovom fizikom odbija mogućnost miješanja zemaljskoga i nebeskoga područja. Nakon tumačenja nebeskih tijela i prirodnih pojava, Kosednar prelazi na astrološke opise i praktične astrološke priloge. Detaljno opisuje svaki planet i pridružene mu odgovarajuće kvalitete.

Potom se u tekstu razmatra prolazak Sunca kroz područje Zodijaka te u skladu s gibanjima planeta u odnosu na zviježđe životinjskoga pojasa izlažu karakteristike svih zodijačkih znakova. Nakon opisnoga dijela, dani su sistematizirani

12 Kosednar kao predložak spominje Regiomontanusovo djelo, ali nigdje ne navodi o kojem je djelu iz Regiomontanusova opusa riječ. 
astrološki podatci smješteni u tablice s prikazom vremenskih razdoblja vladavine pojedinih planeta. Vrijeme u tim tablicama računa kao u rimsko doba. Takvi sati variraju dužinom ovisno o godišnjem dobu. Dnevni sati dobiju se tako da se period od izlaska do zalaska sunca podijeli s dvanaest. Isti postupak ponavlja se za noćni interval od zalaska do ponovnoga izlaska Sunca. Na temelju Kosednarove tabele moguće je odrediti za svaki pojedini "sat" koji planet dominira svojim utjecajem. Koristeći se tim prikazom i uz dodatna astrološka tumačenja, Kosednar iznosi niz astrološko-higijenskih uputa za svakodnevni život. Savjeti se odnose na konzumiranje hrane i pića, odabir povoljnoga vremena za kupanje, spavanje, upute o simptomima i zaštiti od različitih vrsta bolesti te postupcima liječenja. Iznesene naputke Kosednar sistematizira u astrološke tablice, koje u stupcima nose oznake zodijačkoga znaka, a u redcima se nižu brojne svakodnevne aktivnosti. U skladu s tradicionalnom astrološkom praksom, i Kosednar piše o meteorološkim promjenama i prognoziranju vremena pod utjecajem nebeskih tijela. Pravila o promjenama u atmosferi izvodi na temelju promatranja svjetlosti Mjeseca, Sunca i zvijezda te opažanjima vezanim uz gibanja, oblik i boju oblaka. Tomu dodaje i predviđanja vremena koja se temelje na letu ptica, ponašanju životinja, promjenama na predmetima, zvukovima i događajima iz neposrednoga ljudskoga okruženja. Uz svoja predviđanja temeljena na analizi vjetrova prilaže i sliku vjetrova s glavnim karakteristikama. Od ostalih oblika predviđanja vremena po svojoj specifičnosti izdvaja se metoda i sustav prognoza koji se izrađuje na temelju znakova u božićnoj noći i danima koji za njim slijede. Prvo se opisuje mogućnost proricanja na temelju analize vjetrova koji pušu u božićnoj noći. Time se predviđa uspjeh ili neuspjeh u poslovanju, bolesti, neprilike, ratovi, međuljudski odnosi i drugo. Na danu Božića bazira se još jedan način prognoziranja, izveden iz nedjeljnoga slova, odnosno dana u koji sam Božić pada (ponedjeljak, utorak i dr.). Sustav predviđanja koji se temelji na Božiću dopunjava se i zaokružuje predviđanjima koja se dobivaju analizom prvih dvanaest dana koji slijede po Božiću. Prema Kosednaru, tih dvanaest dana simboliziraju i određuju vrijeme kroz cijelu godinu. Knjiga završava astrološkim prilogom naslova Od Orszagov y Glavni Varaszev kojih y pod kojem Neba znamenyem jeszu raznamenuvanye i dodatkom popisa različitih genealogija.

\subsection{Astrološki rukopis đakona Ivana Maurovića}

Među brojnim još neobjavljenim rukopisima koji pripadaju hrvatskoj jezičnoj baštini nedvojbeno je zanimljiv astrološki rukopis đakona (žakna) Ivana Maurovića, sastavljen 1772. u gradu Krku (Veji). Zajedno s naslovnom, rukopis opseže 58 nepaginiranih stranica maloga formata. Naslovljen je: Knige mnogo lipe $i$ koristne ukoihse nahayayu pianete od svih misecev u komuse çovik rodi $i$ skimi zlamenyi, $i$ stomuse u xivotu dogodi, i kada ima umriti upisana po xaknu ivanu mavrovichu. Na naslovnoj je stranici označeno mjesto i godina nastanka rukopisa (U veyi. letta M.DCC.LXX.II). Taj je rukopis jedan od dokaza da je astrologija u 18. stoljeću bila popularna unatoč novim spoznajama i znanstvenim pogledima koji joj nisu bili skloni. Na početku rukopisa autor se u uvodnom dijelu obraća čitaocu tu- 
mačeći mu nakanu knjige. U svladavanju svakodnevnih problema istovremeno preporučuje molitvu Bogu, ali i poznavanje astroloških naputaka i predviđanja koje donosi u knjizi. Maurović piše:

»Molim stazza pridobroga kako brata pridragoga

Da gospodar koji bude

Ove knigge, unapridak

Nepogubiju nego uzbude

darzat napomgliu ov lip trudak

Zaki mnoge jesu danke potroseni od jednoga

Da bude obragnen od demonske vlasti, tako moli Boga.

Ovdi poçimgliu Pianete

Od miseza ukomuse Rodi

Çovik i skimi zlamenyi, i

Kakomu jumase dogoditi:

Ovo stange dobro u glavi i hoches razumiti.

Od misecza ukomuse Rodi« (Maurović, 1772, 2-3).

Sadržaj knjige može se prema obrađenim temama razdijeliti u tri dijela. Prvi dio opseže 37 stranica i uglavnom donosi različite opise glavnih čovjekovih osobina i događanja koja će ga pratiti tijekom života. Daju se naputci koji se strukturiraju i dijele prema spolu i mjesecu u kojem je čovjek rođen. Tako se za mušku osobu rođenu u siječnju predviđa:

»Miseza Genara

Ako Rodise mux na drugo Leto

bude bolestan, nekase çuva od potresa, i od ognya, i od svoyih lyudi: i od tuyih, zlom srichom budese muçit tya do smerti svoye, poyde iz doma, i nechega poznati nigdar pronese roditelyov xivot: i u xalost upade, iu tudyu zemlyu proyde

Potech ili hitrost rukami, i nogami:

Tekuch glavu razbiye.: yest straslyiv, çinyenyem sramežlyiv, od postenih lyudi ali çastnih postovan bude: i bude u mnogoy obiteli ali çelyadi, pervimu umru Groma oblaçnoga hochese boyati, kada germi pod Drivo neka negre daga grom neubiye: od xeleza ohromi, bude hitar razumom krotak, licem sramelzyiv zlamenye yima na siyi, i nabedri, 
i na ruci: preminutye ima na.

24. Leta, ako to proyde xive . 89.

Lett, kadase razboli neka osterze

Ovnu ali Sskopzu roge, i odçela

Vlas ilivana i masla nekase

Maxe i zdrav bude.« (Maurović, 1772, 3-4).

Za osobu ženskoga spola rođenu u siječnju stoji:

»Ako Rodise Divojka, plosna lica

bude, obliçya mala, nekase: çuva

potresa, i od ognya, i od tuyih ly-

udih, i od svoyih, zlom srichom

hochese mucit, perviyoy mux

umre, i drugoga opet vazme,

i stim xive dobro svise budu çu-

dili nyoy: pasyu uyi bude mu-

dra; i ucini starost dobru i niye-

dnoga, Dobra nebude lissena:

zlamenye yima na visoti ali

na glavi, i na dimnyah: premi-

nu yimana . 24. Letta ako to

Proyde hoche biti xiva . 84. Let-

ta kozyega mesa da da neyi:

ali neblaguye: niti koze od glavi

vruka ili neka yischeumuxu.« (Maurović, 1772, 5).

Prvi dio rukopisa donosi predviđanja načinjena prema vremenu rođenja, rastumačena u osnovnim crtama s ciljem da navještaju okvirna zbivanja i glavne osobine pojedinca. Govore o događanjima koja će pojedinca pratiti tijekom života. Predviđanja se iznose sustavno za sve mjesece u godini, ali se nigdje eksplicitno ne spominju zodijački znakovi. Kako Maurović skupine dijeli prema mjesecu rođenja, donekle bi se mogla uspostaviti okvirna analogija prema horoskopu i zodijačkim znakovima, međutim, u tom dijelu teksta autor ih nigdje ne navodi, premda mu je zasigurno u pisanju morao poslužiti određeni astrološki predložak.

Prvi dio rukopisa donosi opise općih karakteristika i predviđanja događaja u životu pojedinca koji se dovode u vezu s mjesecom rođenja, drugi dio rukopisa započinje općenitim pregledom dobroga i lošega znamenja, odnosno Maurović u tom dijelu teksta razmatra različite aspekte života u suglasju s dobrim i lošim znakovima. U uvodu drugoga dijela poziva se općenito na tradicionalne autoritete i spominje stare filozofe (Maurović, 1772, 36), ali još uvijek se ne navode na eksplicitan način zodijački znakovi. U tom dijelu rukopisa dan je popis dana u kojima nešto jest ili nije dobro započinjati (Maurović, 1772, 37-41). Slične priloge nalazimo u srodnoj kalendarskoj literaturi iz 18. stoljeća, u kojoj su takvi prilozi bili uobičajene rubrike. Navode se dani u kojima je dobro ili loše saditi, 
sporove započinjati, graditi, kupati se, kosu i nokte šišati, zaručivati se ili ženiti, na put kretati, u posao se upućivati i slično. U tom dijelu teksta Maurović se u navođenjima poziva na različite argumente i autoritete te navodi i događaje iz Biblije, primjerice

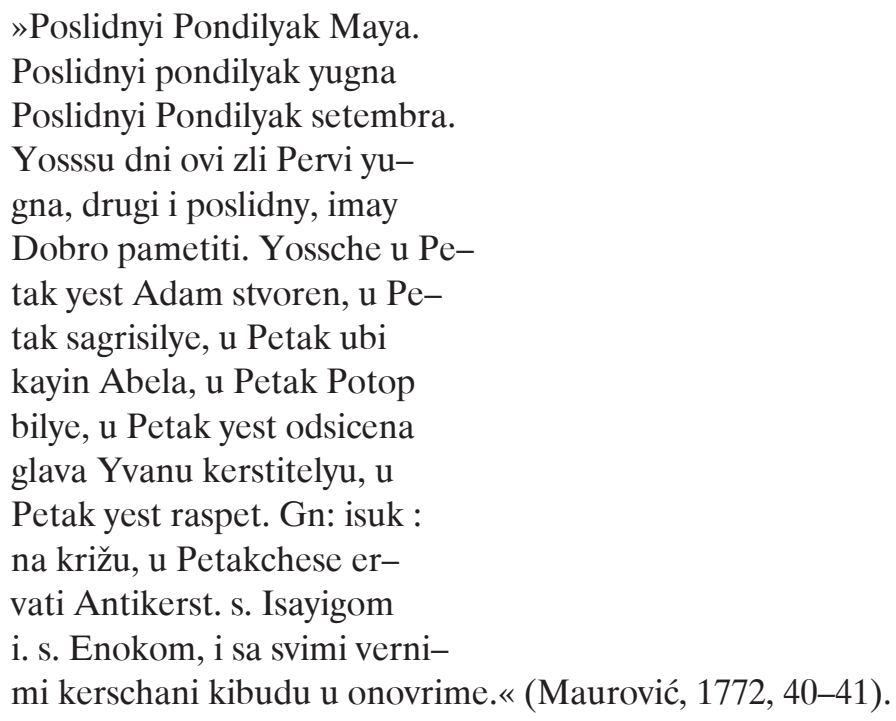

Rukopis na različite načine prezentira dobre i loše predznake. Ponekada Maurović ta znamenje donosi na temelju dana u tjednu:

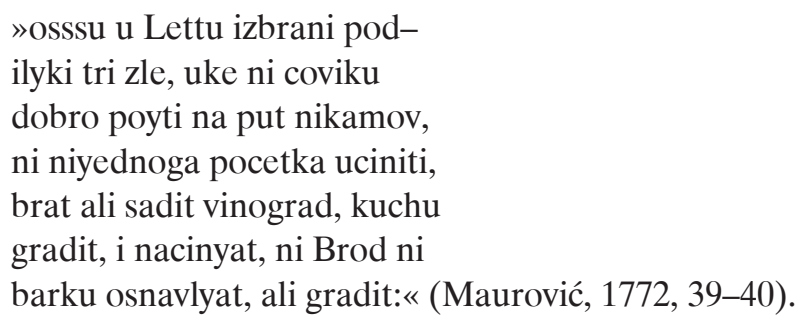

Pored toga, dio predviđanja temelji na čovjekovoj fizionomiji i njegovim sposobnostima. Maurović izdvaja i navodi pojedine ljudske karakteristike, znakove, vještine i osobnosti te u vezi s njima predviđa stanja i događanja koja će ga pratiti tijekom cijeloga života:

»Ovosu sinyali od Potresenya svega života, ki kažu kachese coviku prigodit. Najpervo, Akoli potrepche za uhom desnim kaže pribitak: alivo kaže žalost: Zatilak kaže plac ako desno zlo kaže, a livo dobro, i ober- 


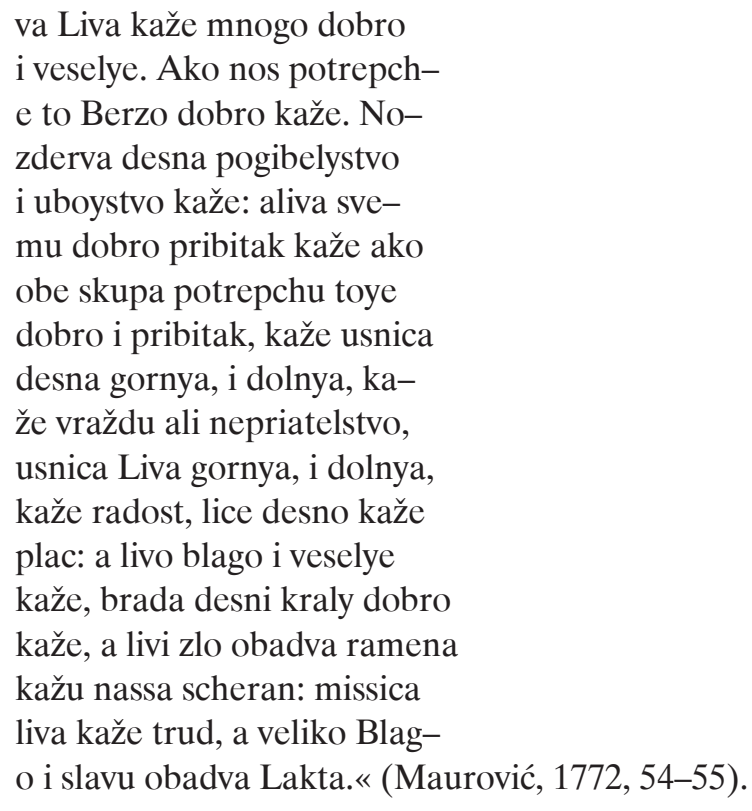

Posljednji, treći dio rukopisa koristi se horoskopskim znakovima i daje astrološke prognoze koje se temelje na vladavini pojedinih znakova. U tom dijelu rukopisa tekst je oblikovan kao svojevrsni pregled ili kalendar dobrih i loših dana, a proricanja su izvedena na temelju vladavine pojedinoga astrološkoga znaka. Autor tako u skladu s astrološkim tumačenjem piše:

»Sada pocinye kalendar od dne-

vov kisu u miseci kada rado

biva zlo vrime tri dni pred

zvezdom ali po nyoy.

Miseca setembra; i. 2. strilac.

3. 4. kozal. 5. 6. Dvoyak ili.

blizanac: 7. 8. Rak. 9. 10.

Yunach. 11: 12.13.14.15.16.17.

18: 19: 20: 21: 22: 23: Divoyka:

24: 25: mirila: 26: 27: ovan:

28: 29: 30: strilac.« (Maurović, 1772, 41).

Slične priloge kao u Maurovićevu rukopisu također nalazimo kod drugih hrvatskih kalendara i srodne literature iz 17. i 18. stoljeća, u kojima su takvi prilozi bili uobičajene rubrike te su Mauroviću takva djela možda poslužila kao neka vrsta predloška za pisanje toga njegova priloga.

Kraj trećega dijela rukopisa bavi se astrometeorologijom, ali i prognozama vremena koje se jednim dijelom temelje na pučkoj tradiciji i usmenoj predaji. 
Prilog o proricanju vremena započinje odlomkom naslova Ono što učitelji govore o prognozama. Daje se sustav općih prognoza i predviđanja vremena za tekuću godinu koji se bazira isključivo na danu u tjednu na koji te godine pada Božić. Maurović prognozirajući opće karakteristike vremena piše:

»Ako Roystvo Isukerstovo doyde u nedilyu, to zima dobra, i Letto dobro bude, a xetva daxyena, i suha: yesen daxyena, i protulitye dažyeno: a skotom oxeti mnogo: meda dovolye, vina namesta, a dici pomor.

Ako Roystvo Isukerstovo doyde u pondilyak, tozima tesna ili uska dobro, i protuliche dobro; xetva dobra, a vetri veliki budu: yesen lipa, a vina dovolye, i bolesti mnoge na mesta, a pcelam pogibel mnoga.

Ako Roystvo Isukerstovo pride utorak, zima velika, i snixna, prihodyenya vodam: a plodom pogibel, skotom smert nazimcem ali ssilyeži bude: vocha obilye, protuliche daxyeno, xetva suha, yesen dobra, usilnost plavayuchim namesta pogibel.

Ako Roystvo Isuk:vo doyde u sredu to zima zla, i protuliche daxyeno, xetva suha, yesen dobra i vetrena, a poche pomalo vode mnogo, izbranim narodom smert mnoga, yesen daxyena, skotom pogibel muxem, smert malo meda bude, vrime naprassno, ali naglo, ali narocito. Ako Roystvo Isukerstovo : doyde u cetertak: to zima Lahka, i vedra mnogo, yesen vetrena: kaxe sidba svaka dobra, meda obilye, a sedim lyudem pogibel velika bude. 


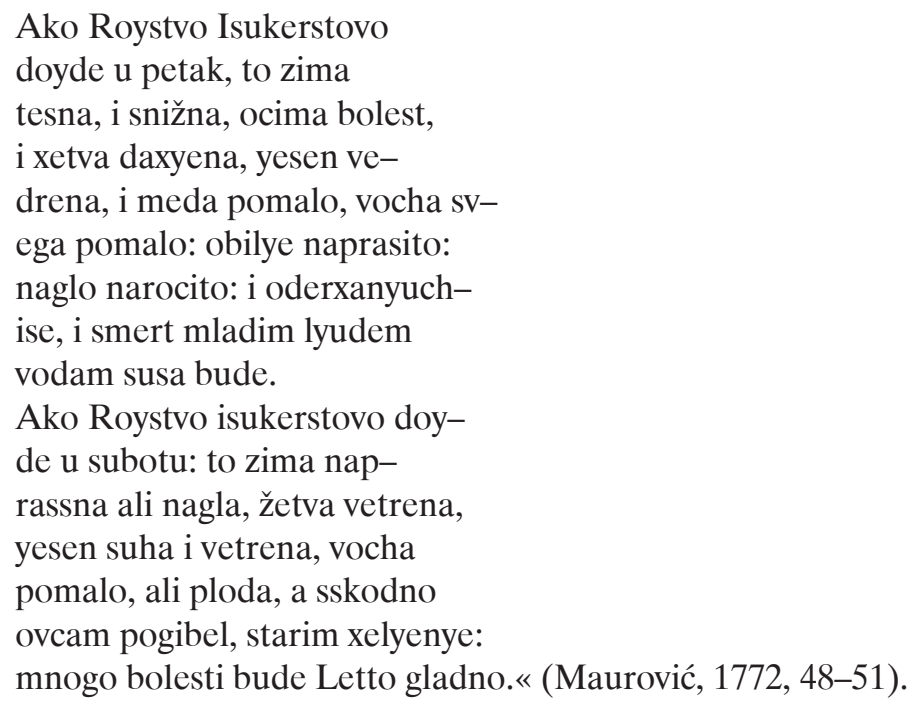

Prognoze vremena u različitim oblicima i formi prisutne su u svim kalendarima toga doba i srodnom pučkom štivu. U odnosu na godišnje kalendare, astrometeorologija je u još većoj mjeri prisutna u stoljetnim kalendarima, te se autor mogao u pisanju toga priloga poslužiti postojećom pučkom literaturom. Primjerice, slična je predviđanja na temelju dana Božića davao i Kosednar, a javljali su se i u prvim tiskanim kalendarima na hrvatskom jeziku. Pored navedenih predviđanja vremena za tekuću godinu koja se baziraju na danu u tjednu u koji te godine pada Božić, Maurović daje još jedan sustav prognoza kroz godinu koji se bazira na predviđanju prema danu u tjednu na koji pada dan 1. prosinca. U vezi s time piše:

»Ako nastane Decembar u
Pondilyak, to zima dobra:
Protuliche dažjeno, i vedr-
eno i obilye svemu svitu:
i bolest i nagla smert lyudem.
46

Ako nastane Decembar utorak, to zima velika, i snižna: jesen Dažjena: žetva dobra: sada ali ploda malo: skotom smert, bisnost ili yaznost nareschena.

Ako nastane Decembar u sredu, to zima zla, žetva

dobra, senice mnogo, vina mnogo, skotom pogibel, a mužem smert. 


\begin{abstract}
Ako nastane Decembar u cetertak, to zima velika i vetrena bude, žetva dobra: yesen vetrena sada ali ploda mnogo mnogo meda a malo bude.
\end{abstract}

47

Ako nastane Decembar u Petak, to zima naprassna, ali narucita ili nagla bude: vetra mnogo: vina mnogo: ocima bolest, dici pogublyenye i pomorstvo.

Ako nastane Decembar u sobotu, to zima lyuta yesen rodna: ploda malo ovcam smert.

Ako nastane Decembar u Nedilyu, to zima dobra, yesen dažyena, žita suha: meda mnogo: vina malo: skotom pogibel: mladim lyudem smert.« (Maurović, 1772, 45-47).

Astrološke savjete o dobrim i lošim danima Maurović dopunjava pregledom dobrih i loših utjecaja pojedinoga znaka. O tom izlaže u cjelini naslova Znaj kad hoćeš putovati pogledaj u kojem je znaku taj dan piše:

»Znay da kada hochess putovati pogleday nakom zlamenyu stoyi oni dan Ako bude u ovnu, nekodipoginess.

Ako bude u yuncu, nehodi razbitchete.

Ako bude u Dvoyci, poydi hoches srichan biti.

Ako bude u Raku, poydi srichate tira.

Ako bude u lavu, poydi nechesse veliko xalostiti, ni veseliti.

Ako bude u divoyki poydi srichno bude.« (Maurović, 1772, 57). 
Analizom Maurovićeva rukopisa može se zaključiti da pored astrologije njegov tekst donosi i druge različite oblike proricanja te praktične upute koje se ne baziraju samo na astrologiji, nego na pučkoj tradiciji i vjerovanjima. U skladu s time, pored astroloških daje i druge praktične, ponekad i naivne upute kako postupati u životu vezano uz utjecaj planeta. Maurovićev rukopis dragocjena je građa za rekonstrukciju ondašnje razine znanja i stavova koji su se u to vrijeme zastupali.

\section{Zaključak}

Sačuvani astrološki tekstovi na hrvatskom jeziku iz 18. i 19. stoljeća pokazuju da astrologija, premda se je još od 17. stoljeća prestala pojavljivati u filozofskim koncepcijama i izgubila je status znanstvene discipline, ostaje zastupljena u širim društvenim krugovima. Postupno iz znanstvenih sfera u kojima se smatrala korisnom znanstvenom i praktičnom disciplinom, prelazi u pučku literaturu, u kojoj se prožima s praktičnim tekstovima za svakodnevni život i pučkom tradicijom. Astrološki prilozi javljaju se u raznolikom štivu: od godišnjih i stoljetnih kalendara, almanaha i pučkih priručnika za svakodnevni život do matematičkih udžbenika. Dragocjena su građa za rekonstrukciju ondašnje razine znanja i stavova koji su se u to vrijeme zastupali. Ti tekstovi ne sadrže astrološku teoriju, nego donose naputke iz astrološke prakse, a njihovi autori ističu da ljudskim životima i cijelim univerzumom upravlja Bog. Nastali u vrijeme kada je bilo vrlo malo literature na hrvatskom jeziku, imali su ulogu u opismenjavanju i prosvjećivanju hrvatskoga puka. Bili su utjecajno i popularno štivo, te su starije astrološke priloge u fragmentima prenosili i mlađi priređivači. Uz astrološke tekstove u njima se daju osnovni astronomski podatci i tumačenja koja se uklapaju u Aristotelovu prirodnu filozofiju, a stavovi koji se zastupaju vrlo su zastarjeli u odnosu na znanstvene ideje koje su se tada razvijale u znanosti i poučavale u školstvu toga doba.

\section{Literatura:}

Borić, Marijana (2014). Doprinos franjevaca kalendarskoj tradiciju u Hrvata. U: Pavao Knezović i Marko Jerković (ur.), Zbornik radova sa znanstvenoga skupa "Fra Emerik Pavić i franjevci u kontinentalnoj Hrvatskoj" (str. 337-354). Zagreb: Hrvatski studiji Sveučilišta u Zagrebu.

BORIĆ, Marijana. 2016. Pavao RitterVitezović i njegov utjecaj na tradiciju hrvatskih kalendara. U: Zbornik radova sa znanstvenog skupa „Pavao RitterVitezović i njegovo doba (1652-1713)“, Zagreb, 26.-28. rujna 2013., Hrvatski studiji sveučilišta u Zagrebu,:279-299.

Dadić, Žarko (1982). Povijest egzaktnih znanosti u Hrvata II: Egzaktne znanosti u Hrvata od kraja 18. stoljeća do početka 20. stoljeća. Zagreb: Sveučilišna naklada Liber.

Dadić, Žarko (2004). Egzaktne znanosti u Hrvata u doba prosvjetiteljstva. Zagreb: Matica hrvatska.

DESPOT, Miroslava. 1972. „Kalendar, njegov postanak i razvoj“. Kaj, časopis za kulturu i prosvjetu V/12: 23-24. 
Maurović, Ivan (1772). Knige mnogo lipe i koristne ukoihse nahayayu pianete od svih misecev u komuse çovik rodi i skimi zlamenyi, i stomuse u xivotu dogodi, i kada ima umriti upisana po xaknu ivanu mavrovichu. [Rukopis.]

Mikloušić, Tomaš (1819). Stoletni kalendar iliti Dnevnik stoletni horvatski do leta 1901. kažuči po Tomašu Mikloušiču, plebanušu vu Stenjevcu ispisan i na svetlo van dan. Zagreb.

Skuhala Karasman, Ivana (2013). U potrazi za znanjem o budućem: Predviđanje u srednjovjekovnoj i renesansnoj prirodnoj filozofiji - H. Dalmatin, F. Grisogono i J. Dubrovčanin. Zagreb: Institut za filozofiju.

VITEZOVIĆ RITTER, Pavao. 1692., 1698., 1699, 1705, Meszecsnik hervatzki, Zagreb.

The Transfer of Astrology from the Sphere of Science to the Field of Folk Literature in the Texts of Croatian Authors of the 18th and 19th Century

\section{Marijana Borić*}

\section{Summary}

The paper discusses the astrological texts of Croatian authors produced after the 17th century when astrology left the field of science and philosophy and entered into other genres which were meant for a broader readership. Various forms of astrological contributions are described which were found in the calendar and related literature and, in particular, a few astrological manuscripts written in the Croatian language are analyzed. It is demonstrated that the shift made by astrology from the sphere of science into the field of folk literature did not diminish interest in astrological content. This can be concluded from the example of 18th and 19th century texts. The paper analyzes their content, templates, and domains with a view to better understand the Croatian astrological tradition and its place and definition in the corpus of the Croatian literary heritage. The texts described were not intended for a narrow intellectual stratum, but rather for a wider circle of readers and do not contain explanations on how horoscopes or theoretical astrology are needed to carry on astrological practice. Croatian manuscripts portray and interpret astrological predictions in the way they appear in folk tales printed from the 16th century onward in Western Europe. In Croatian calendars, astrological contributions have been on the rise since the end of the 17 th century, as for example in Vitezovic's calendars, which were printed as a series of calendars dating from the second half of the 18th century. The same can be seen in the second part of the Mathematical Handbook of Mate Zorčic Arithmetic which includes an astrological circle. They were also printed in the first half of the 19th century in annual calendars and especially in a centuries-old Croatian calendar, which, due to their popularity, were published several times, and their astrological contributions were transmitted by younger editors also. The manuscripts described were intended for the leisure and instruction of the common folk, written as manu-

* Marijana Borić, Ph.D., Croatian Academy of Sciences and Arts. Institute for the History and Philosophy of Science. Address: Ante Kovačića 5, 10000 Zagreb, Croatia. E-mail: mbuljan@ hazu.hr 
als for everyday life, determining their content as well as their purview. Although they deal with astrological contributions, the authors emphasize that our world is completely in the hands of God's providence. Since in the texts described, there is no prophecying of human destiny, it was not unusual for priests and friars to believe in such predictions. The texts provide basic information on the characteristics of particular planets, which are in line with general medieval and Renaissance astrological attitudes and which had been incorporated into Aristotle's natural philosophy. The fact that they were written in the Croatian language at a time when few works existed in the language of the common people, places these texts into the framework of the effort to enlighten those who are easily manipulated. In addition, they are a valuable asset for the reconstruction of the level of knowledge and attitudes which prevailed at that time. However, that which stands behind the attitudes represented in Croatian astrological texts from the 18th century was already very conservative in relation to the point of view not only of scientists, but also of what they represented in the field of education in Croatia at that time.

Key words: astrology; astronomy; philosophy; Paul Ritter Vitezović; Josip Franjo Kosednar; Ivan Maurović; astrological manuscripts; literature 